NBER WORKING PAPER SERIES

PROVINCIAL AND LOCAL GOVERNMENTS IN CHINA: FISCAL INSTITUTIONS AND GOVERNMENT BEHAVIOR

\author{
Roger H. Gordon \\ Wei Li \\ Working Paper 16694 \\ http://www.nber.org/papers/w16694
NATIONAL BUREAU OF ECONOMIC RESEARCH
1050 Massachusetts Avenue
Cambridge, MA 02138
January 2011

We would like to express our gratitude for the comments and suggestions that we received from Joseph Fan, Alex Gelber, Hua Li, Zhigang Li, Randall Morck, Bernard Yeung and participants at presentations at Tsinghua University, the NBER pre-conference in Cambridge MA, and the NBER-CUHK conference in Hong Kong on "Capitalizing China." We would like to thank CKGSB for its hospitality and financial support. The views expressed herein are those of the author and do not necessarily reflect the views of the National Bureau of Economic Research.

NBER working papers are circulated for discussion and comment purposes. They have not been peerreviewed or been subject to the review by the NBER Board of Directors that accompanies official NBER publications.

(C) 2011 by Roger H. Gordon and Wei Li. All rights reserved. Short sections of text, not to exceed two paragraphs, may be quoted without explicit permission provided that full credit, including $\odot$ notice, is given to the source. 
Provincial and Local Governments in China: Fiscal Institutions and Government Behavior Roger H. Gordon and Wei Li

NBER Working Paper No. 16694

January 2011

JEL No. H7,O17,O38,O53,P16,P2,P43

\begin{abstract}
$\underline{\text { ABSTRACT }}$
What are the incentives faced by local officials in China? Without democratic institutions, there is no mechanism for local residents to exercise "voice". Given the hukou registration system, local residents have little opportunity to threaten "exit" if they are unhappy with local taxes and spending. This paper explores an alternative source of incentives, starting from the premise that local officials aim to maximize the jurisdiction's fiscal residual (profits), equal to local tax revenue minus expenditures on public services. In a Tiebout setting with mobile households, this objective should lead to efficient provision. What happens, though, if firms and economic activity but not people are mobile? The paper examines the incentives faced by local Chinese officials in this context, and argues that the forecasted behavior helps to explain both the successes and the problems arising from local government activity in China.
\end{abstract}

\author{
Roger H. Gordon \\ Department of Economics 0508 \\ University of California, San Diego \\ 9500 Gilman Drive, Dept. 0508 \\ La Jolla, CA 92093 \\ and NBER \\ rogordon@ucsd.edu \\ Wei Li \\ Darden School of Business Administration \\ University of Virginia \\ 100 Darden Boulevard \\ Charlottesville, VA 22903 \\ w19d@virginia.edu
}




\title{
Provincial and Local Governments in China: Fiscal Institutions and Government Behavior
}

\author{
Roger H. Gordon, UCSD, NBER and $C K G S B^{*}$ \\ Wei Li, Darden School of Business and CKGSB
}

June 2010

Provincial and local (hereafter "local") governments in China play an important role in the overall economy. To begin with, local budgetary revenue in recent years is around $8 \%$ of GDP, extra-budgetary revenue (largely income from land) comes to another $3 \%$ of GDP, budgetary expenditures are close to $14 \%$ of GDP, and extra-budgetary expenditures adds another $2.5 \%$ of GDP (see Table 1 ). This scale of activity is broadly comparable to that of state and local governments in the United States, where own tax revenue is around $13 \%$ of GDP and expenditures are 16\% of GDP. Local governments in both settings have primary responsibility for education, local infrastructure, and local public services.

The similarity largely stops there, however. In the United States, local governments are mainly financed by property taxes and user fees, and state governments by a combination of personal income taxes and sales taxes. In China, until 1994, local governments were mainly financed through a tax on the profits and sales of non-state firms. Since then, they have received a fraction of the VAT and corporate profits tax collected in their jurisdictions, and all the revenue from personal income taxes, business taxes, and (until recently) taxes on agriculture. ${ }^{1}$

Chinese local governments also play a much more central role in the local economy than do local governments in the United States, controlling the allocation of land, and in the past, exercising substantial controls over the allocation of bank credit. The initial growth in China at the beginning of the economic reforms in fact is largely attributed to the initiative of local governments in setting up township and village enterprises (TVEs) and other non-state firms (Gordon and $L i, 2005$ ).

\footnotetext{
${ }^{*}$ We would like to express our gratitude for the comments and suggestions that we received from Joseph Fan, Alex Gelber, Hua Li, Zhigang Li, Randall Morck, Bernard Yeung and participants at presentations at Tsinghua University, the NBER pre-conference in Cambridge, MA, and the NBER-CUHK conference in Hong Kong on "Capitalizing China." We would like to thank CKGSB for its hospitality and financial support.

${ }^{1}$ See Gordon and $L i(2005)$ and Hussain and Stern (2008) for more discussions on the evolving public finance in China.
} 
Oversight over local government in China is also far different than in the United States. In the United States, oversight occurs through both voice and exit. Local officials are elected by residents, so they can be removed from office if residents are not satisfied with outcomes. In addition, local residents can vote with their feet and leave a poorly performing jurisdiction, putting pressure on local officials to keep current residents satisfied. In China, by contrast, neither voice nor exit plays a major role in affecting the incentives faced by local officials. There are no local elections above the village level, ${ }^{2}$ so officials face no threat of being voted out of office. ${ }^{3}$ The threat of exit is also constrained, since Chinese are subject to the hukou system, a registration system that ties individuals to their current location. In addition, farmers are tied to their land, since there is not a well functioning market for selling or leasing this land, due to their lack of legal ownership of the land.

If neither voice nor exit serve to provide incentives to local officials in China, what does affect their incentives? Oversight from the central government certainly plays an important role, as emphasized by $X u$ (2010). Local officials are appointed by higher levels of government and are evaluated by the central government based on a range of criteria. The central government also mandates that certain intergovernmental transfers from the central government be matched by provincial and local funds and then be used for specific purposes, e.g. education and health care, which constrains the choices of local officials.

In practice, though, local officials still have substantial discretion. For example, even if monetary expenditures on particular tasks can be monitored, it is difficult to monitor the quality of the resulting services. The country is large, and the resources available to the central government to oversee subnational governments are very limited. Even when oversight exists, the effects of this oversight on the chance of promotion (or demotion) of local officials carries much weight only for the very best and very worst officials, as judged by the observed criteria, since most officials are neither promoted nor demoted. In addition, mandated use of funds, or explicit standards of performance, have the drawback that these standards may not be well suited for many jurisdictions, given the tremendous variation in conditions over a large and diverse country. The information used in making these decisions can also be manipulated by local officials, undermining the effectiveness of these incentives.

In practice, therefore, the quality of the remaining incentives faced by local officials inevitably plays an important role. How well designed are these incentives? The better these incentives are designed, the greater the decentralization of decision-making that can

\footnotetext{
${ }^{2}$ Since the $1980 \mathrm{~s}$, villagers have been allowed to experiment with various forms of self-government, often by electing village management committees, to fill the vacuum left after the demise of the People's Communes (O'Brien and $L i, 2000$ ). In 1998, village elections and village self-government were codified into law. However, elected village officials often enjoyed little fiscal autonomy. Democratic choice of officials has not to date been extended to higher levels of government.

${ }^{3}$ In the official hierarchy in China, village officials are not considered government cadres, even though they are often on the government payroll.
} 
comfortably be undertaken. The focus of this paper is then on the range of incentives faced by officials beyond direct oversight from the central government.

Our key hypothesis is that the welfare of local officials is heavily dependent on the amount of government revenue collected in their jurisdiction, minus the amounts they need to spend to provide services to local residents. These residual fiscal profits are under the control of local officials and can easily be used for their personal benefit. The size of these residual profits is affected by the allocation choices made by local officials, so they implicitly serve as an incentive contract. If local revenue depends on the profits of local firms, for example, then officials have a personal incentive to increase these profits.

Given existing tax structures and existing sources of extra-budgetary revenue, what economic incentives do local officials face? What economic choices would local officials then be expected to make, given these incentives? When incentives have changed over

time, what changes in behavior would we expect to see? What are the key sources of inefficiency in the allocation of resources by local government forecast based on existing financial incentives? What would be the forecasted effect of possible fiscal reforms on the efficiency of the allocation decisions made by local officials?

The organization of the paper is as follows. Section 1 summarizes briefly the role of voice and exit in affecting the incentives faced by local officials in the United States, as explored in the past academic literature. Section 2 develops an alternative model in which the incentives faced by officials depend on the tax revenue they receive minus whatever they need to spend on local public services. We develop this model using the institutions that have existed in China during the reform period. In section 3, we then examine how these incentives changed over the course of the reform period, as the tax law changed and as market reforms were introduced. Section 4 then examines the additional incentives faced by officials due to national government control over their possible promotion or demotion. Section 5 considers how a range of policy reforms would affect the incentives faced by local officials, and section 6 provides a brief summary.

\section{Traditional models of government oversight}

We begin with a summary of the U.S. literature on the forms of oversight of local officials, and why on paper we would then expect to see officials making choices that are largely in the best interests of residents.

One source of oversight is the election process. Each potential official proposes a platform to voters. Voters choose that candidate whose proposed platform provides them the highest utility. If candidates simply care about being elected and voters are homogeneous, then, in equilibrium, each candidate's platform will maximize the utility of voters. Inefficiencies can arise due to differences in the preferences of the median voter compared with the overall costs versus benefits of a project, as emphasized by Buchanan and Tullock (1962). Candidates, though, have their own preferences, and can be influenced by special 
interests. They are not obliged to follow through on their campaign promises. Voters also face a free rider problem, having no personal incentive to vote or to be informed about the candidates. The quality of oversight through the voting process is therefore uncertain on net. Banerjee and Duflo (2006), for example, find in India that voters provide surprisingly poor oversight over officials.

More central to the literature on fiscal federalism is the Tiebout model. Under this model, officials propose a tax structure and spending package and gain utility from any tax revenue left after financing promised expenditures. ${ }^{4}$ Residents then choose where to live and firms where to locate, with land prices adjusting to generate an equilibrium residential allocation. Competition among communities, if sufficiently intense, pushes net fiscal profits down to zero, induces officials to provide the package of public services residents are willing to pay for, and forces them to finance these expenditures with user fees (or head taxes if all residents benefit equally from the spending) and to provide the services at minimum cost. This competition is most intense if residents are costlessly mobile, if they can carry their income with them, and if there are many competing communities. In equilibrium, when competition is intense, fiscal outcomes should be efficient.

Officials in China, though, are not subject to either voting pressures or much pressure from the mobility of potential residents, given the hukou system. Even though people are not mobile, however, economic activity is mobile: Local firms face intense competition in the (inter)national economy. The aim of this paper is to make use of the Tiebout framework to explore what outcomes would be expected when officials act to maximize net fiscal profits, as defined based on the existing institutions in China, given that economic activity, but not people, are mobile across jurisdictions.

\section{Incentives created by the source of tax revenue: general model}

In this section, we focus on how the available sources of revenue affect the incentives faced by Chinese officials. Our setup follows the structure of the Tiebout model in that the utility of officials depends on their net "fiscal profits": tax revenue, profits from firms owned by the local government, plus income generated by land rents minus expenditures on public services.

We begin by laying out a general model with the following stylized institutional features. With the hukou system in place, we assume that labor is not mobile across jurisdictions (Wang and Zuo, 1999), ${ }^{5}$ but it can freely move between jobs within the jurisdiction. We assume for now that capital cannot move across jurisdictions. ${ }^{6}$ Land is owned by the

\footnotetext{
${ }^{4}$ We will refer to government revenue minus expenditures as net fiscal profits.

${ }^{5}$ Economic reforms have gradually increased labor mobility, an issue we discuss in Section 3.

${ }^{6}$ Economic reforms have relaxed control over the allocation of capital. In section 3, we presume local government control over the allocation of capital until 1994 and market allocation after 1994.
} 
government. Farmers have been given use rights for their plots and must be compensated if the government shifts this land to other uses. Use rights on other land can be allocated, rented, or sold to firms and households for a finite number of years. In the next section, we then relate these more general assumptions to the particular institutions that existed during various time periods under the reforms in China.

Firms can be privately owned or owned by local governments. ${ }^{7}$ Privately-owned firms in each industry $i$ located in the jurisdiction face a tax at rate $\tau_{i}$ on their profits, denoted $\pi_{i}$, an excise tax at rate $s_{i}$ on their sales, plus an implicit tax denoted by $\kappa_{i}$ on their capital. Here, $\pi_{i}=p_{i}\left(1-s_{i}\right) Q^{i}-w L_{i}-\left(r+\kappa_{i}\right) K_{i}-n_{i} A_{i}-u_{i} G$, where $p_{i}$ is the output price (which the jurisdiction takes as given), $Q^{i}=Q^{i}\left(L_{i}, K_{i}, A_{i} ; G, R\right)$ is local output produced in industry $i$ using labor $\left(L_{i}\right)$, domestic capital $\left(K_{i}\right)$, and land $\left(A_{i}\right)$, with local infrastructure $G$ aiding production and local regulations $R$ affecting productivity. Here, $w$ is the local wage rate, $r$ is the interest rate charged by banks on loans to the firm (set nationally), and $n_{i}$ is the implicit rent the government charges industry for use of land, while $u_{i}$ is a fee (if any) charged for use of $G$, which at most equals the marginal product of $G$. Depending on the time period, officials may control the allocation of domestic capital across local firms through their oversight of the local banks. Not only do tax rates differ by industry, but they also may differ by type of firm, with the national government receiving all the revenue from state-owned firms that it controlled, but local governments at times receiving all the tax revenue from both private firms and firms set up by the local government.

For government-owned firms, the government receives not only the tax revenue from the firms, but also the after-tax profits, $\left(1-\tau_{j}\right) \pi_{j}$. In total, it therefore simply receives the entire pre-tax profits from these firms. We assume that the government has designed the incentives faced by firm managers so that they make allocation decisions to maximize the government's objective function.

Depending on the time period, officials may also receive revenue from agriculture, both through explicit taxes and through requiring farmers to sell output to the government at a below-market price. Assume for simplicity that the tax revenue from agriculture equals $\sigma p_{f} F$, where $\sigma$ is the implicit tax rate, $p_{f}$ is the market price for agricultural output, and $F$ is the quantity produced, with $F=F\left(L_{f}, K_{f}, A_{f} ; G_{f}, R_{f}\right)$. Here, $G_{f}$ is another set of public services aimed at agriculture, provided at a user charge of $u_{f}$, while $R_{f}$ represents regulations affecting agriculture.

Farmers have use rights for an area of land $A_{f}^{0}$ without paying explicit rent. If officials reallocate some of this land to industrial or residential uses, they must compensate farmers by paying them the marginal product of land used in agriculture, an amount we denote by $c \equiv(1-\sigma) p_{f} F_{A}$, where $F_{A}=\partial F / \partial A_{f}$ is the marginal product of land. ${ }^{8}$ Similarly, the wage rate firms must pay to attract local workers satisfies $w \equiv(1-\sigma) p_{f} F_{L}$. To simplify

\footnotetext{
${ }^{7}$ In this analysis, we ignore firms owned by the national government, since allocations to these firms are largely controlled by the national government. For simplicity, we also ignore foreign subsidiaries.

${ }^{8}$ Throughout, we use subscripts of a function to denote partial derivatives.
} 
the subsequent notation, assume that all units of output are redefined so that $p_{i}=p_{f}=1$.

The government provides services to each household, $G_{h}$, which the household in part pays for through a user fee $u_{h}$. Let $n_{h}$ denote the rent received per unit of land $A_{h}$ allocated to housing. Market-clearing rents can be expressed by $n_{h}=q\left(A_{h}, w \sum_{i} L_{i}\right)$, where $q$ is decreasing in $A_{h}$ and increasing in the income of workers.

For simplicity, we start by assuming a fixed total supply of each factor to the jurisdiction, e.g., $\sum_{i} A_{i}+A_{f}+A_{h}=A^{T}$, where the superscript $T$ signifies the total amount of a factor available in the jurisdiction. Given the lack of mobility, total factor supplies are clearly fixed for labor and land. For the moment, we assume that the supply of capital to the jurisdiction is fixed as well, based on the deposits under the control of local banks. We also assume that factors are fully employed, so for any given allocation of factors to industries, the agricultural output is simply $F\left(L^{T}-\sum_{i} L_{i}, K^{T}-\sum_{i} K_{i}, A^{T}-\sum_{i} A_{i}-A_{h} ; G_{f}, R_{f}\right)$.

Assume that firms with $i \in I_{P}$ are privately owned while firms with $j \in I_{G}$ are owned by the government. The objective of officials is to maximize the sum of tax revenue from privately owned firms, profits from government-owned firms, agricultural taxes, and land rents, minus compensation to farmers and minus the net cost (net of user fees) of public expenditures on local infrastructure and minus the implicit cost of effort expended on regulations: ${ }^{9}$

$$
\begin{array}{r}
\sum_{i \in I_{P}}\left(\tau_{i} \pi_{i}+\kappa_{i} K_{i}+s_{i} Q^{i}+n_{i} A_{i}\right)+\sum_{j \in I_{G}}\left(Q^{j}-w L_{j}-r K_{j}\right)+\sigma F+q A_{h}-c\left(A_{f}^{0}-A_{f}\right) \\
-G\left(1-\sum_{i \in I_{P}} u_{i}\right)-G_{f}\left(1-u_{f}\right)-N^{T} G_{h}\left(1-u_{h}\right)-e(R)-e_{f}\left(R_{f}\right)
\end{array}
$$

Here, $N^{T}$ is the size of the local population. Officials then allocate land and capital and choose how much to spend on each form of public service to maximize expression (2.1). Local wage rates and labor allocation are determined by the local labor market.

We assume that officials maximize this expression over the time period they are in office, so that each expression implicitly reflects the present value of taxes and expenditures during this time period, and $A_{f}^{0}$ measures the amount of land used by farmers when the official takes office. Decisions clearly are affected by the official's time horizon, since some effects of policy changes show up quickly whereas other effects may materialize only after the official leaves office. ${ }^{10}$ We also ignore any agency problems that may exist within the local government, and assume that all decisions are based on the above objective. ${ }^{11}$ Another apparent omission is side payments from firms or individuals that aim to change

\footnotetext{
${ }^{9}$ For simplicity, we assume that $G$ and $G_{f}$ are local public goods, so that costs or quality of service do not depend on the number of users.

${ }^{10}$ If the official can "sell" his position to his successor, though, then the price paid can capture these future effects of policy changes, implicitly giving officials a longer time horizon.

${ }^{11}$ Since an official may be removed from office if those reporting to him are unhappy with his performance, an official faces a strong incentive to align his interests with those of others in the local government.
} 
government decision. As argued by Grossman and Helpman (1994), such side payments would ideally be designed so that officials take full account of how their decisions affect the profits/utility of the firm/individual paying the bribe. If a private firm makes such payments, for example, then the official would take into account the effects of any decision on the firm's pre-tax profits, as is the case for firms owned by the local government. ${ }^{12}$

What decisions are then forecast, given this objective function for local officials? Consider first the allocation of labor to government-owned firms in industry $j$. The first order condition satisfies

$$
Q_{L}^{j}=w+\sigma F_{L}-q_{L} A_{h}-(1-\sigma) F_{A L}\left(A_{f}^{0}-A_{f}\right),
$$

where the subscripts in $Q^{j}$ and $F$ denote first-order and second-order partial derivatives with respect to capital, labor, and/or land. ${ }^{13}$ With full employment as assumed, the extra labor allocated to industries has to be taken from agriculture, raising the marginal cost of labor to the government by an amount equal to the foregone agricultural tax revenue $\sigma F_{L}$. In addition, extra industrial workers lead to greater rental income from residential housing, and lower compensation payments to farmers due to any drop in the value of land when farmed less intensively.

Note that managers of these firms, if they instead made hiring decisions to maximize after-tax firm profits, would seek a labor force satisfying $Q_{L}^{j}=w /\left(1-s_{j}\right)$. Local governments have financial incentives to force managers of government-owned firms to hire more workers than they would otherwise choose to as long as $w+\sigma F_{L}-q_{L} A_{h}-(1-$ $\sigma) F_{A L}\left(A_{f}^{0}-A_{f}\right)<w /\left(1-s_{j}\right)$. This condition holds as long as $s_{j}>\sigma$. In this case, excise taxes unduly discourage employment in government-owned firms relative to agriculture, while extra government employment provides various added benefits to the government's budget. Managers of government-owned firms certainly claim that they are forced to employ many more workers than they would wish to.

Consider next the allocation of domestic capital to government-owned firms in industry $j$. The first order condition satisfies

$$
Q_{K}^{j}=r+\sigma F_{K}-(1-\sigma) F_{A K}\left(A_{f}^{0}-A_{f}\right)
$$

Given the local resource constraint, the extra capital can be viewed as coming from agriculture. Now $r$ is paid by the government rather than by farmers, introducing one cost. The next term reflects the foregone tax revenue from agriculture due to the drop in capital there. The final term measures the gain due to the fall in land values in agriculture from

\footnotetext{
${ }^{12}$ Private firms were at times referred to as "wearing a red hat," perhaps reflecting the fact that side payments existed so that local officials treated these firms equivalently to government-owned firms.

${ }^{13}$ In general, wage rates can adjust. For simplicity here and later, we ignore changes in wage rates, on the grounds that there has been enough surplus labor in agriculture that any such changes are too small to matter.
} 
the drop in use of capital there, resulting in less compensation being paid to farmers for any land shifted out of agriculture to industry.

Efficient allocation of capital requires that $Q_{K}^{j}=F_{K}$. In contrast, we conclude that $Q_{K}^{j}<F_{K}$, implying too much investment in industry than in agriculture on efficiency grounds, as long as $r$ is small and $\sigma<1$.

Note that investment in agriculture increases when $\sigma$ increases. With a higher tax rate, the benefits to the government of investment in the sector rise, leading to additional investment. This counter intuitive result arises because the government is making allocation decisions based on the implications for tax revenue, rather than having farmers make the decision based on implications for their after-tax profits.

Consider next the allocation of domestic capital to private firms. Compared to allocating capital to government-owned firms, there are two disadvantages to allocating capital to private firms. First, private firms hire fewer workers than the government would like them to, since their hiring decisions are characterized by $Q_{L}^{i}=w /\left(1-s_{i}\right)$, rather than by equation (2.2). To that extent, private firms make less effective use of extra capital. In addition, the government receives only a fraction of the resulting marginal product of capital equal to $T_{i} \equiv s_{i}+\tau_{i}\left(1-s_{i}\right)<1$. For both reasons, the required marginal product on capital allocated to private firms must be higher to compensate for these two offsetting disadvantages to private allocations.

Turn now to the allocation of land for industrial and residential uses. The first-order condition for land allocated to government-owned firms is

$$
Q_{A}^{j}=F_{A}-(1-\sigma) F_{A A}\left(A_{f}^{0}-A_{f}\right)
$$

By shifting an extra unit of agricultural land to industrial use, the government pays $(1-\sigma) F_{A}$ to farmers as compensation and bears a fall in agricultural revenue by an amount $\sigma F_{A}$, for a combined opportunity cost of $F_{A}$. Allocations are efficient if there are no further considerations, so that $Q_{A}^{j}=F_{A}$. However, leaving less land in agriculture raises its marginal product, so the government needs to provide more compensation to farmers by an amount $-(1-\sigma) F_{A A}\left(A_{f}^{0}-A_{f}\right)$. While this offsetting effect slows the reallocation of land from agriculture to industry, leading to higher interim values for land in industry than in agriculture, each generation of official inherits a lower $A_{f}^{0}$ and will choose to make further land reallocations as long as $Q_{A}^{i}>F_{A}$. This reallocation continues until officials take office inheriting a value of $A_{f}^{0}$ equal to the allocation they find optimal. At this optimal allocation, we find that $Q_{A}^{j}=F_{A}$. After enough turnover of officials, we can expect land to be allocated efficiently between agriculture and government-owned firms.

Note, however, that each generation of officials acts in its own self-interest, ignoring the effects of its sales on the welfare of other generations of officials. If these different generations of officials could collude, acting as if there were one official in office indefinitely, then as a group they would take into account the effects of land sales on the compensation paid 
to farmers on all land ever taken out of agriculture, and not just on the land removed from agriculture while that one official is in office. With such collusion, the sales price would be permanently higher for non-agricultural land than for agricultural land. Interestingly, the central government has a policy to preserve at least 1.8 billion mu of agricultural land, ostensibly because of concerns over food security. ${ }^{14}$ An alternative motivation could be that this national policy serves as a means of collusion among different generations of officials.

Consider now the first-order condition that arises when officials consider reallocating land from government-owned firms to private firms. Here, we find that $Q_{A}^{i}>Q_{A}^{j}$ for two reasons. First, while the government receives rent on extra land allocated to private firms equal to the resulting after-tax profits and also receives the extra tax revenue, summing to $Q_{A}^{i}$, it suffers a loss due to the fall in equilibrium land rents: $\left(1-T_{i}\right) Q_{A A}^{i} A_{i}$. The government, being a monopoly supplier of land, therefore restricts land allocations to private firms in order to drive up rents. Second, the private firm hires fewer extra workers as a result of the extra land than would the government-owned firm, reducing further the value of this land allocation.

For residential land, the government also acts as a monopoly supplier. It compares the marginal revenue it receives to the same types of terms as above measuring the opportunity cost of the land.

One implicit assumption in the above derivation is that officials compare the flows of rent in each use. In fact, they need to pay a lump-sum compensation to farmers reflecting the present value of the land in agriculture when land is taken from agriculture. If the trade-off that officials face is between this lump-sum payment to farmers and an increased flow of rents from industry during the limited time period the official remains in power, they would favor leaving land in agriculture. The land use policies and practice since the late 1990s have instead allowed officials to sell rights to the land when it is reallocated to industry. Officials therefore compare present values. The respective rents are then divided by a discount rate, giving them much more weight in the above expressions. The discount rates need not be the same, however. In particular, farmers face a harder time acquiring funds, since farmland cannot be used as collateral, unlike industrial or residential land. Farmers' discount rate should therefore be higher, generating a factor favoring a reallocation of land from agriculture to industry. In addition, once land has been sold, changes in rents on this land no longer matter for future officials. In particular, the term in equation (2.4) capturing changes in residential rents would now capture changes in rents only on land still owned by the government and changes in value on residential land that will be sold by that official.

What about the choice of expenditures on public services? The choices made by government officials, based on their own self-interest, would be efficient only if local firms

\footnotetext{
${ }^{14}$ This policy imposes limits on the conversion of agricultural land within each jurisdiction, with opportunity costs that vary greatly by jurisdiction. If rights to develop agricultural land could be traded across jurisdictions, these opportunity costs could be reduced.
} 
and individuals together are left unaffected on net by a marginal change in $G .{ }^{15}$ Any benefits to government-owned firms already go in their entirety to the government. The net benefits to private firms, farmers, and workers equal zero, leading to efficient choice, only if

$$
\begin{aligned}
\sum_{i \in I_{p}}\left(1-T_{i}\right)\left(Q_{G}^{i}-Q_{A G}^{i} A_{i}\right)-(1-\sigma) F_{A L} d L_{G}\left(A_{f}^{0}-A_{f}\right) & \\
& -q_{L} A_{h} d L_{G}=\sum_{i \in I_{p}}\left(1-\tau_{i}\right) u_{i} .
\end{aligned}
$$

Here, $d L_{G}$ measures the reallocation of agricultural labor into industry due to the marginal increase in $G$, which, we presume, raises the marginal product of industrial labor.

Incentives on officials are therefore efficient only if user fees fully reflect the direct netof-tax benefits to private firms, farmers, and workers minus any losses they incur due to changes in rents and in compensation payments to farmers. At least for roads with tolls, a firm makes use of these roads to the point where $\left(1-T_{i}\right) Q_{G}^{i}=\left(1-\tau_{i}\right) u_{i}$. Efficiency then requires that the remaining terms on the left hand side of equation (2.5) equal zero. The remaining terms all reflect losses to the private sector. Governments therefore have too strong an incentive to provide these services and would be expected to provide subsidies to the private firms that undertake these infrastructure investments.

Similarly, the choice of $G_{f}$ yields an efficient outcome only if the private sector is left indifferent at the margin to any marginal change in provision of public services. This condition holds if

$$
\begin{aligned}
& (1-\sigma) F_{G}+(1-\sigma)\left(F_{A G}-F_{A L} d L_{G_{f}}\right)\left(A_{f}^{0}-A_{f}\right) \\
& \quad-\sum_{i \in I_{P}}\left(1-T_{i}\right) Q_{A L}^{i} A_{i} d L_{G_{f}}^{i}-q_{L} A_{h} d L_{G_{f}}=u_{f} .
\end{aligned}
$$

$G_{f}$ raises the marginal product of agricultural labor and therefore causes a marginal reallocation of industrial workers back into agriculture. ${ }^{16}$

For incentives on government officials to be efficient, user fees must fully reflect the netof-tax benefits to farmers from extra public services to agriculture, plus any net benefits farmers receive through increased compensation for land transferred out of agriculture, plus the net benefits the non-agricultural sector receives from lower rents on commercial and residential property due to a migration of people back to agriculture. If farmers make use of public services until marginal benefits and marginal costs are equal, so that

\footnotetext{
${ }^{15}$ This condition on marginal incentives is sufficient if the second-order conditions are satisfied, e.g., decreasing returns to scale.

${ }^{16}$ The term $d L_{G_{f}}^{i}$ in equation (2.6) denotes the marginal reallocation of labor from agriculture to industry $i$. Since the reallocation is from industry $i$ back into agriculture, $d L_{G_{f}}^{i}<0$.
} 
$(1-\sigma) F_{G}=u_{f}$, then efficiency again requires that the remaining terms on the right hand side of equation (2.6) sum to zero. All these terms reflect a net benefit to the private sector, implying that the private sector benefits on net from additional expenditures on public services to agriculture. The government, ignoring these benefits, then provides too few such services.

Expenditures on $G_{h}$ are efficient only if the dollar benefits per household equal their required user fee. In particular, education and health care services would be provided only if costs are fully covered through user fees. This forecast is consistent with the claim we have heard that education and health care have become "commodities" under the reforms, and helps explain why the national government finds it hard to induce local governments to provide these services for free to residents.

Finally, what can we say about regulatory policies? Again, decisions by government officials are efficient only if the private sector is left indifferent at the margin to any changes in regulation. As with public services, the private sector benefits from any increase in aftertax profits, and is affected by any changes in land rents that arise (directly or indirectly) in response to these extra profits. With no extra user fees, though, there is no offsetting price that can adjust so that the private sector can be left indifferent on net. As a result, officials face inadequate incentives to put effort into industrial regulations benefiting private firms, though they would face efficient incentives if there were separate policies for governmentowned firms. For similar reasons, there are inadequate incentives to regulate agriculture well.

While local governments in China control the allocation of land and did in past years control the allocation of capital, they don't control the allocation of labor. From their perspective, too much labor ends up migrating to lightly taxed industries away from more heavily taxed industries. As a result, local governments can potentially gain through making use of any further instruments to shift production from lightly taxed to heavily taxed industries. One such instrument is controls over trade between their jurisdiction and the rest of China. In particular, each local government has an incentive to restrict imports in heavily taxed industries and restrict exports in the most lightly taxed industries. By shifting the composition of local production towards goods that are more heavily taxed, government revenue in the jurisdiction increases. Largely, this increase comes at the expense of government revenue in other jurisdictions, who lose export markets for their most highly taxed goods and have a harder time buying elsewhere the most lightly taxed commodities. National prices then fall for the more heavily taxed goods, and rise for the more lightly taxed goods, weakening any further incentive to intervene to restrict trade. These negative fiscal externalities result in an inefficient choice of government policies from the joint perspective of local governments, providing a motivation for the national government to intervene to lessen these trade distortions. Consistent with these forecasts, Young (2000) and Bai et al. (2004) report evidence that local governments restricted trade patterns, leading to too many firms of too small scale in the heavily taxed industries. 


\section{Application of model to different time periods}

We next use this general model to forecast the behavior of government officials during particular sub-periods under the reforms in China, and how it should have changed over time.

\section{$3.1 \quad 1979-1994$}

The initial allocation of resources in 1979 favored heavy industries at the expense of agriculture and industries that catered to consumer demands. The government collected revenue with a turnover tax, the industrial and commerical tax, on state-owned firms, by directly controlling the use of state-owned firms' profits, and by taking grain from peasants and leaving them just enough for subsistence. Table 2 shows that between 1978 and the early 1980s, government relied primarily on remitted profits from state-owned firms and revenue from the industrial and commercial tax for its revenue. To economize on the cost of revenue collection, the government used price scissors to channel profits and turnover taxes (which were included in official prices) to a few industries located in large cities. Agricultural goods were priced the lowest, followed by raw materials, energy, industrial goods, consumer necessities, and then consumer durables. To capture price scissors, we assume

$$
p_{1}^{0} \geq p_{2}^{0} \geq \ldots \geq p_{I}^{0} \geq p_{f}^{0} \equiv 1,
$$

so the lower numbered industries are higher-profit-margin consumer durables industries. Here, the total number of industries is $I$, and the superscript ${ }^{0}$ denotes planned prices. The national government then used its control over the allocation of factors to produce those goods demanded at these prices.

We can characterize the resulting allocation under central planning as a market allocation subject to a set of excise taxe rates, with the highest tax rate on consumer durables and the lowest on agriculture, sufficient to induce firms to produce those goods demanded by consumers at the prices $p_{i}^{0}$

As part of the initial reforms, local governments obtained control and cash flow rights for new firms they set up or sponsored as well as for existing small and medium-sized SOEs and even some large SOEs. The local government not only received the tax payments from these firms based on the newly introduced excise and profits taxes, but also controlled the use of the firms' remaining after-tax profits. As a result, the objective of local officials was to maximize the sum of pre-tax profits and land rents, minus the cost of public expenditures on local infrastructure and minus the effort expended on regulations: ${ }^{17}$

$$
\sum_{i}\left(p_{i}^{0} Q^{i}-w L_{i}-r K_{i}\right)+\sigma F-G-G_{f}-G_{h}-e(R)-e_{f}\left(R_{f}\right)
$$

\footnotetext{
${ }^{17}$ At least initially, user fees were unusual.
} 
This objective is a special case of equation (2.1), but with no private firms and no income from land. ${ }^{18}$ Since the excise taxes used to maintain the initial prices did not affect the allocation decisions of local officials, local governments faced undistorted incentives but prevailing prices that differed sharply from marginal costs. They therefore faced strong incentives to shift production toward goods that had previously faced high implicit tax rates. They were in an effective position to do this, since local officials had control over the allocation of existing bank credit among different firms. ${ }^{19}$ While existing industrial workers were guaranteed a planned wage rate, a labor market nonetheless arose since new "contract" workers could be hired at a market wage rate (Gordon and Li, 1995).

What do these conditions imply for allocation decisions? The first order conditions with respect to capital and land satisfy

$$
\begin{aligned}
Q_{K}^{j} & =\left(r+\sigma F_{K}\right) / p_{j}^{0}, \\
Q_{A}^{j} & =\sigma F_{A} / p_{j}^{0} .
\end{aligned}
$$

Conditional on the initial prices, on efficiency grounds the allocation of factors within industry should have been efficient, though too much capital and land would be shifted out of agriculture into industry, assuming that the interest rate has been set below the market-clearing level. Since the initial prices were not market-clearing prices, however, the resulting allocations led to surplus output in the industries with artificially high prices and shortages in the industries with artificially low prices. The resulting competition among local governments to gain market shares in high-margin industries led to over-capacity and inefficiently small scales in those industries, exposing the incompatibility of pricing under the plan with decentralized decision-making.

These growing surpluses and shortages quickly forced the national government to introduce a dual-track pricing system, whereby a fixed quantity, rationed among firms, must be sold at the original prices, and all further output must be sold at market prices $(L i, 1999)$. With undistorted incentives on local governments and market prices for all marginal transactions, allocation decisions within industry should indeed have been efficient. Empirical studies by Gordon and $L i$ (1995), Groves et al. (1994), and $L i$ (1997) confirm the efficiency enhancing impact of the reform in the 1980s. It was also documented in $L i$ (1997) that, between 1980 and 1989, more investment did flow to industries that had higher combined taxes and (after-tax) profits per yuan of sales and that product market competition among enterprises did bring about marked improvements in total factor productivity. Competition, however, significant reduced state-owned firms' profits. Table 2 shows significantly smaller remitted profits and the presence of large subsidies to cover state-owned firms' losses in the late 1980s.

\footnotetext{
${ }^{18}$ Residential housing was provided by each firm for its employees rather than being rented from the local government.

${ }^{19}$ We assume that so little land could yet profitably be used in industry that $A_{f}^{0} \approx A_{f}$.
} 
However, given that $\sigma<1$, there would be too little land allocated to agriculture. With $r \approx 0$, there would also be too little capital investment in agriculture, as is apparent in the data. Figure 1 shows that the share of capital construction investment allocated to agriculture started from a small $4.5 \%$ in 1980 and declined steadily to less than 1\% in 1994. By comparison, the share of capital contruction investment allocated to industry remained above $60 \%$ between 1985 and 1994 .

In spite of an unclear legal environment, some private firms did enter during this period; see Figure 3 for evidence of a rising share of industrial output produced by nonstate firms between 1980 and 1993. However, since local governments could keep only the tax revenue from private firms, there would be underinvestment and potentially even no land allocated to private firms, unless private firms provided side payments to local officials (implemented perhaps by registering firms as collectives), to compensate for any lost profits from government-owned firms.

What about public expenditures? First, without (much of) a private sector and no land rents, there are no marginal effects on the private sector of any changes in public services to industry, so government incentives lead to efficient outcomes for $G$ as long as changes in wage rates can be ignored. Agriculture would benefit directly from extra services to agriculture, but without user fees, officials have no reason to take these benefits into account, leading to inadequate incentives to provide $G_{f}$. Without user fees, there are no incentives to provide $G_{h}$ to households. Table 4 shows that shares of budgetary expenditures on programs that support agriculture, education, scientific research, and social subsidies fell between 1991 (the first year we have available data) and 1993, while shares of budgetary expenditures on capital construction and services to industry, communications, and distribution held steady. Extra-budgetary expenditures, if the data were available, would likely be even more biased toward capital contruction than budgetary expenditures.

Finally, what about regulatory policies? With full control over the entire return to improvements in industrial productivity, officials should have invested the efficient level of effort in designing effective regulations for industry. Sharing less in productivity gains in agriculture, they would have invested less effort there. Data in Table 4 on fiscal support from local governments for agriculture and non-agricultural sectors are consistent with this prediction.

In sum, the reforms starting in the early 1980s offered local officials strong incentives for industrial development. These incentives encouraged officials to pour resources into sectors that the planners had previously restricted. Our model forecasts an efficient allocation of factors within industry, but an excessive shift of capital and land out of agriculture.

\subsection{Post-1994}

The Chinese government implemented extensive economic reforms around 1994, with many further gradual changes since then. Our stylized summary of the institutions since 1994 are as follows: 
The dual track system was phased out by the mid-1990s. Planned prices were largely eliminated. This shift in infra-marginal rents, though, didn't change marginal incentives so shouldn't have affected market allocations.

Restrictions on the entry and growth of private firms were substantially eased, resulting in a rapid growth of the private sector (Figure 3). The allocation of factors between private and government-owned firms now becomes a serious choice, making details of the tax system an important issue.

The formal tax structure changed dramatically in 1994. Excise taxes with rates that varied by industry were replaced by: 1) a VAT on mining and manufacturing industries at a uniform rate of $17 \%$, with local governments receiving $25 \%$ of the resulting revenue collected from firms in the jurisdiction; ${ }^{20}$ 2) a business tax (an excise tax on service industries), with the revenue going entirely to local governments; and 3) an excise tax on luxury goods and goods with consumption externalities paid to the national government. In addition, the statutory corporate income tax rate fell from $55 \%$ to $33 \%$. The national government received the corporate income taxes paid by financial institutions and firms controlled directly by the national government, while local governments received the corporate taxes paid by local firms. ${ }^{21}$ A personal income tax was created, with revenues going entirely to local governments. In addition, the national government took control over the administration of the taxes on firms, largely eliminating the ability of local governments to hide the tax liabilities of local firms from the national government.

The impact of this change in tax structure on the share of budgetary revenue between national and local governments is apparent in Table 1. From 1993 to 1994, the budgetary revenue of the national government rose from $2.7 \%$ of GDP to $6 \%$, while the budgetary revenue of local governments fell from $9.6 \%$ to $4.8 \%$. And in 1994, Table 2 shows that state-owned firms stopped remitting profits to governments. In Table 3, we report tax revenues collected relative to GDP under the new tax regime. The VAT, business tax, and the corporate income tax accounted for most of the revenues. Personal income taxes also rose quickly to become the fourth largest revenue source. Tax revenue rose steadily between 1995 and 2007.

These various tax reforms should have had only limited effects on the incentives faced by local officials when allocating factors to government-owned firms: The only change is that the national government now collects some VAT revenue from these firms, so the local government does not receive quite all of the pre-tax profits. However, the private sector becomes increasingly important, in part because of a steady push towards selling off control over firms owned by local governments. After a sale occurs, local governments

\footnotetext{
${ }^{20}$ When first introduced, expenditures on fixed assets were not permitted as a deduction under the VAT. Until 2009, the VAT was production-based rather than consumption-based. In addition, all of the local share of the VAT from a multi-jurisdiction firm goes to the jurisdiction where the firm's headquarters is located.

${ }^{21}$ Since 2002, the national government has received corporate income taxes on all new firms, though local governments continued to keep corporate taxes from existing local firms.
} 
simply receive their share of the taxes collected from these firms, lowering their incentive to allocate resources to these firms.

Another major policy change was to reduce local government's control over the allocation of credit from the banking system, so that loans would be made based on commercial principles. With a commercial market for credit, we then must presume that $r$ becomes a market clearing price. Overall investment in a jurisdiction no longer depends on the amount of bank deposits in the jurisdiction. Some jurisdictions will then be net capital exporters and others net capital importers, leading to a more efficient allocation of capital across the national market.

What can we then say about the relative rates of investment in different types of activity? From the government's perspective, the opportunity cost of investment in a government-owned firm is now simply $r$, so that investment in these firms continues until $Q_{K}^{j}=r$. Private firms would choose to invest until $\left(1-s_{j}\right) Q_{K}^{i}=r+\kappa_{i}$. Taxes discourage investment in private firms, and to an extent, that differs by industry due to variation in VAT coverage or in implicit tax rates on capital. Investment should therefore fall in a firm once it is privatized. Government firms also have a differential advantage in sectors where private firms face higher tax rates.

Farmers continued to face agricultural taxes, but now can choose how much to invest and will do so until $(1-\sigma) F_{K}=r .{ }^{22}$ In the earlier period, we forecast that $Q_{K}^{j} / F_{K}<\sigma$, assuming $r \approx 0$, but now forecast that $Q_{K}^{j} / F_{K}=1-\sigma$. If $\sigma<.5$, we then conclude that capital flows out of government firms into agriculture following the reforms in 1994. A yet larger shift in capital toward agriculture should have occurred more recently following the elimination of taxes on agriculture. Indeed, as shown in Figure 1, the share of capital construction allocated to agriculture rose from $1 \%$ in 1994 to around $3.5 \%$ by 2001, while the share of capital construction allocated to industry fell from $70 \%$ to $60 \%$. Figure 2 also shows that the numbers of tractors per 100 square kilometers of arable land increased rapidly after 1994, and the pace acelerated after 2004 when provinces in China started to reduce and eventually to eliminate agricultural taxes.

When private firms and farmers are left indifferent to adding more capital, however, local governments gain from further capital investment, particularly in private firms, due to the resulting taxes. They can add to the local capital stock by favoring capital-intensive over labor-intensive industries. One way to do this is to continue to restrict imports to the jurisdiction of more capital-intensive products in order to increase demand for local production in these industries.

With the loss of control over the allocation of capital, the remaining control over the allocation of land took on greater importance. Due to the rapid rate of growth in industry and the pressure for large reallocations of land, land allocations became an important issue.

Rather than allocating land specifically to one firm or another, the practice instead

\footnotetext{
${ }^{22}$ Insecure use rights to the land, though, may inhibit investments in agriculture.
} 
has been to auction the land to the highest bidder. The key question is then the amount of land to remove from agriculture and make available for industrial or residential use. Given the institutions prevailing since 1994, we then forecast that too much land would be left in agriculture relative to industry. The excess land in agriculture keeps the auction price high and means that the required compensation to farmers remains low due to the resulting low marginal product of land in agriculture.

Due to the restrictions on land available for industry, industrial rents are artificially high. As a result, land rents have become a major source of finance for local governments in China. UBS economist Tao Wang estimated that the national average extra-budgetary revenue from land auctions is between $17 \%$ and $24 \%$ of total local government revenues. ${ }^{23}$ In coastal cities where property prices have risen sharply since 2003, the contribution of land sales to local government budgets should be significantly higher. This institution is very much reminiscent of the role of land controls in place in Hong Kong, where again the government has limited that allocation of land to industrial and residential uses.

The economic reforms also substantially changed the incentives to finance public services. Part of the change was the growing use of user fees to finance infrastructure as well as services to households. Many services (e.g., highways) are provided by private firms, in principle, financed fully by user fees. Since the private sector as a whole loses at the margin from increased services due to the resulting increases in land rents, local governments gain from increased services and therefore have an incentive to subsidize private firms to provide more services. They can do this by allocating extra land to these private firms, generating an additional source of revenue for these firms.

What can we say about the efficiency of spending on $G_{f}$ ? User fees such as road tolls now equal the after-tax benefit to farmers from the use of public services, e.g., $(1-\sigma) F_{G}=$ $u_{f}$. As seen from equation (2.6), though, allocations are then efficient only if there are no net effects of the extra public services on land rents. However, any extra services to agriculture benefit farmers due to the increase in compensation paid for land removed from agriculture and also benefit the non-agricultural sector through a fall in land rents there. To that extent, government incentives to provide services to agriculture are insufficient.

The model forecasts that $G_{h}$ will be provided only if fully financed with user fees. The model omits, though, several complicating factors affecting, in particular, expenditures on education. For one, more educated workers will be more productive, generating extra VAT revenue. $^{24}$ In addition, educated workers may be a complement to capital investments, benefiting officials by adding to the taxable capital stock in the jurisdiction. Offsetting these benefits, however, more educated workers may be more likely to leave the jurisdiction, e.g., going off to university, lowering the tax base for the jurisdiction. There would then be stronger incentives to provide education at a price below marginal costs in urban areas,

\footnotetext{
${ }^{23}$ Tao Wang, "Understanding Land Transfer and Local Government Debt Problem (in Chinese)," http://cn.wsj.com/gb/20100225/COL174204.asp, accessed on March 9, 2010.

${ }^{24}$ This extra revenue will show up, though, only when these new workers enter the labor force. Officials commonly are reassigned after about three years, and as a result, may ignore most of these benefits.
} 
where workers are less likely to leave if they receive better education.

\subsection{Labor mobility}

Contrary to our assumptions above, there is some labor mobility in China, even if mobility is clearly restricted as seen from the large differences in wage rates between rural and urban and between inland and coastal residents. Officially, individuals need to change their hukou in order to move, requiring approval of both the new jurisdiction and the old jurisdiction. Mobility therefore requires that the worker as well as both jurisdictions benefit. For a move to benefit both jurisdictions, side payments between the two jurisdictions will normally be needed. However, we often see jurisdictions allowing migrant workers to enter without granting them official residence. ${ }^{25}$ Without official residence, however, migrants are not eligible for public services. Our aim in this section is to understand the implications of labor mobility for government incentives. ${ }^{26}$

To begin with, what net benefits does a jurisdiction receive from having workers enter, and to what degree does the answer depend on the skill level of the worker and whether the worker is given hukou status? Making use of expression (2.1), we can calculate the impact on a jurisdiction from a marginal increase in the number of workers. The net benefits/costs of having an extra worker consist of several components. First, the extra output increases sales tax revenue. Second, the extra labor force will generate further capital investment, leading to extra tax revenue both directly due to the implicit tax on capital and indirectly through further increases in sales tax revenue. Third, land rents change: Industrial land rents go up due to the increases in both capital and labor, residential land rents increase due to the larger industrial labor force, but the compensation that must be paid to farmers for any further land taken out of agriculture also goes up since the value of agricultural land increases. Fourth, the new worker must be provided public services, but pays any associated user fees. If user fees do not cover the full cost of services, reflecting for example the pressures from the national government to provide free education, then the jurisdiction loses to the extent that the worker needs such services. The demand for services is reduced substantially if the worker is not allowed to shift hukou to the jurisdiction.

The size of these net gains will vary by jurisdiction and by type of worker for a variety of reasons. The gain in sales tax revenue depends on the industrial composition of the jurisdiction. For example, if the jurisdiction is mainly agricultural, then their gains are small given that agriculture is no longer taxed. The gain is also larger in jurisdictions with a high local wage rate, since then the marginal product of labor is higher, leading to larger increases in sales tax revenue. The increase in capital investment would normally be larger the more capital intensive the key industries in the jurisdiction are. Capital

\footnotetext{
${ }^{25}$ Many coastal provinces in China are home to millions of migrant workers from inland provinces who hold only temporary residency permits.

${ }^{26}$ There are in fact experiments under way at the time of the writing of this paper investigating the economic implications of easing migration restrictions.
} 
intensity should be higher in part when the local wage rate is higher. To the extent that capital and skilled labor are complements, then skilled labor attracts more capital, leading to a greater increase in tax revenue from capital. The increase in industrial land rents would normally be greater the larger the increase in capital and labor, while the higher compensation to farmers for their land is less important in more urban jurisdictions.

What migration do we then expect to see? Workers will want to move to jurisdictions that provide them higher utility. We assume that their utility can be expressed by $U\left(w, q, G_{h}, u\right)$ : Utility should be increasing in the wage rate, falling due to higher land prices, and higher when the package of public services and user fees is more attractive. In order to attract workers, a jurisdiction faces an incentive to provide cheaper housing and more attractive public services. To the extent that communities gain from extra workers, competition can force down the price of public services and housing below the values we forecast above.

When will the old and new jurisdictions together agree to shift the migrant's hukou? Without a change in hukou, the old jurisdiction normally loses from the migration. Consequently, with unrestricted migration, the resulting rate of migration can be excessive since neither the migrant nor the new jurisdiction takes these losses to the previous jurisdiction into account. If the previous jurisdiction does not receive compensation, though, jurisdictions that are threatened with a loss of residents can create barriers to migration, for example making it difficult to transfer agricultural land.

The new jurisdiction per se has an incentive to avoid making a side payment to the old jurisdiction. Only migrants who receive a change in hukou are eligible for public services, providing a further incentive on the new jurisdiction not to seek to change the worker's hukou. However, without a change in hukou, workers face a higher implicit price for public services, perhaps because their best option is to leave their family in their old jurisdiction where services continue to be available. Because of these higher costs, workers would be willing to migrate only if other aspects of the new location are more attractive, e.g., wage rates are higher. Given the added costs beyond the marginal costs of the services when the family is divided between two locations, there should be a feasible agreement between the two jurisdictions to change the worker's hukou. This agreement may even involve the old jurisdiction compensating the new one for the provision of public services to the worker's family. This pressure to change hukou status is limited though if the migrants do not place much value on the resulting public services, compared to the cost of these services.

We have heard anecdotes of jurisdictions trying to prevent entry of unskilled workers. Why might this be? Industries vary in their relative demands for skilled versus unskilled workers. The industrial composition of the jurisdiction should then in equilibrium adjust so that demands for different skill levels match supplies. Given that some industries pay more in taxes than others, a jurisdiction would then want to adjust the skill composition of its labor force to match the desired skill composition of the more heavily taxed industries. If skill-intensive industries are more heavily taxed, as seems plausible, then jurisdictions have an incentive to increase the ratio of skilled to unskilled workers, by preventing the 
in-migration of unskilled workers. For example, the government of Zhongshan, a city in Guangzhou province, started to implement a scoring system to screen non-resident applicants. The system assigns 80 points for a college degree, 90 points for a graduate degree, 10 points for owning property in the city, and one point for each 50,000 yuan investment in the city for up to 10 points. The city government would offer a migrant worker and his dependents basic medical care if he has a cumulative score at or above 60, job training if his score reaches 70, equal access to public services that hukou-holders are entitled to if his score reaches 90, and hukou if he accumulates a score of 100 or above. The scoring system makes transparent the preference of the local government for migrant workers.

\section{Incentives generated by promotion and retention proce- dures}

Another important source of incentives for local officials in China arises from the implications of their performance for possible promotion to higher positions, or possible demotion (or worse). The national government attempts to regulate directly the behavior of local officials, compensating for the poor financial incentives faced by local officials by retaining some elements of centralized allocations.

Current interventions by the national government take many forms. For one, the national government has ruled that local governments are obliged to provide free education through grade nine. We found above, though, that providing such free education is against the interests of local officials. Given the difficulties faced by the national government in keeping tabs on a huge country, any such attempts at oversight will likely have only modest effect. ${ }^{27}$ Given this problem, the national government more recently has provided additional national funds to help free students of any remaining fees for education up through grade nine, requiring that local governments provide matching funds of their own for this purpose. Our model forecasts, though, that local officials have an incentive to provide education only if the resulting fees fully cover the cost. They have no incentive to provide a free education even when the national government finances a fraction of the costs.

Over time, the national government has made increasingly explicit its mechanism for judging the qualifications of local officials for possible promotion: Judgments will be based in good part on the rate of growth in national tax revenue from the jurisdiction. The preferences of other top officials in the jurisdiction are also taken into account. How do these added incentives affect our prior results?

Previously, the objectives of officials reflected the fiscal profits they controlled while in office. National promotion policies induce officials to give some weight as well to national

\footnotetext{
${ }^{27}$ For example, education can be free of tuition, but there can be many fees imposed (for uniforms, books, etc.).
} 
tax revenue. The national government collects $75 \%$ of the overall VAT payments, increasing the importance of sales tax revenue. They collect all of the corporate tax revenue from new firms and from state firms, tending to equalize the incentives local officials face to aid one category of firm compared to another. The national government, though, does not collect any revenue from agriculture, so the added incentives increase the weight placed on industry compared with agriculture. Since the VAT does not allow deductions for capital, promotion incentives create yet more of an incentive to favor capital-intensive industries over other sectors.

Having promotion decisions depend on the preferences of other top officials in the jurisdiction helps address any agency problems in the jurisdiction. In a hierarchical structure, officials at any given level in the hierarchy require the support of those in the next lower level. Given these links at each level of the hierarchy, even the top official implicitly needs to worry about the preferences of the lowest ranked officials. While leading to an alignment of interests among all officials, though, this structure does not in itself create any reason to care about the welfare of non-officials, supporting our omitting the utility of residents from the objective function for local government officials.

The national government also affects the incentives faced by local governments through its control over the allocation of intergovenmental transfers of funds. Funds are in part allocated based on geography, going particularly to inland provinces. Since residents lose access to any benefits resulting from these transfers if they leave the jurisdiction, these transfers result in less migration of workers from inland regions that receive greater per capita transfers. Since we forecast excessive migration previously, transfers can then help ease the resulting misallocations.

\section{$5 \quad$ Alternative policies and the resulting incentives for local officials}

Since promotion standards and centralized allocations of funding cannot easily be tailored to local conditions, these interventions inevitably lead to misallocations. The interventions may still improve on outcomes to the extent that local officials face poorly designed financial incentives. To the degree that financial incentives were altered so as to lead to more efficient decentralized allocations, the central government would face less pressure to intervene directly. How then would the inefficiencies generated by current sources of finance for local governments be affected by plausible changes in the tax structure?

Under existing incentives faced by officials, outcomes are inefficient on many dimensions. Governments make use of their controls over the allocation of land to keep prices

high for industrial and residential uses, and low for agriculture. Since any movement of resources from agriculture to industry generates more tax revenue, officials will make use of their control over public services and regulations to aid industry relative to agriculture. They will make use of their regulatory powers to favor more highly taxed (often the more 
capital-intensive) local industries. To finance public services with user fees, the required fee must equal the average cost of the service per user in order to break even. But the service is used efficiently only if the fee also equals the marginal cost per user. High tolls on the roads, for example, unduly discourage usage. Migration of workers is limited, leading to dramatic differences in wage rates across locations, suggesting large inefficiencies from the misallocation of workers. Along each dimension, what policy changes might lead to more efficient decentralized allocations?

Taxes avoid favoring one industry over another, for a given local population, only if the taxes collected are the same for each worker, regardless of the industry in which a worker is employed. This equalization of taxes paid per worker would exist under a variety of alternative tax structures. In principle, it arises with a consumption-based VAT, since here taxes paid depend on each worker's consumption expenditures but not on the industry where they are employed. ${ }^{28}$ A retail sales tax creates equivalent incentives, but also can have a high evasion rate due to the many small retail firms that are hard to monitor and due to the ease of cross-border shopping. A third alternative is to confine such a consumption tax to those goods that can easily be monitored, including for example residential housing, ownership of a car, and a range of other goods such as electricity consumption and phone usage. Differential rates by form of consumption induce a misallocation of consumption across commodities, but the efficiency costs here are normally second-order. Under these alternative tax bases, revenue does not depend on the industry in which a worker is employed. Revenue also increases as income per capita and the population in the jurisdiction rise, giving officials an incentive to raise per capita income and to attract new residents. For these reasons, it is not surprising that the principal sources of tax revenue among local governments in the United States are a property tax and a local retail sales tax (that covers in practice around a third of overall consumption).

What policy alternatives might lead to a more efficient allocation of land? Since officials are compensated heavily based on the price differential of land in alternative uses, they face strong incentives to shift land to higher-value uses. Officials shift land too slowly on efficiency grounds to take advantage of their market power. However, due to the turnover of officials, each generation of official will choose to transfer additional land to higher-value uses. As long as this transfer occurs through a sale rather than a lease of land, the resulting drop in rents on inframarginal units sold by previous officials is borne by past buyers rather than by the government. According to equation (2.4), allocations therefore converge towards one with $Q_{A}^{j}=Q_{A}^{i}=F_{A}$ as the additional transfers by each generation of official $\left(A_{f}^{0}-A_{f}\right)$ converge toward zero. Misallocation of land therefore seems to be primarily a transition problem in the absence of any mechanism through which different generations of officials could collude, acting as if there were one official in

\footnotetext{
${ }^{28}$ In practice, though, a consumption-based VAT is hard to enforce, since it is very difficult to monitor the flow of goods into and out of the jurisdiction.. It would also be difficult to monitor trade within a multi-jurisdictional firm, given the use of transfer pricing.
} 
office indefinitely. ${ }^{29}$

One other current source of inefficiency arises from the high user fees for public services. When the average cost exceeds the marginal cost for a service, as should be the case for highways, for example, then the services are underutilized. Even when the marginal and average costs are equal, as could be true for education, users may face binding liquidity constraints that prevent them for undertaking an investment in human capital even if the eventual rate of return is very high. As seen above, though, officials have no incentive to provide these services unless doing so generates enough extra revenue to cover the costs.

What alternatives exist? Mobility is the mechanism emphasized in the Tiebout model to induce officials to provide the efficient level and composition of services. To the extent people are mobile, officials are pressed to adopt policies that attract potential residents and induce existing residents to stay. With intense competition, policies end up maximizing the utility of residents and are efficient. To attract additional residents, the key means available to officials is to reduce the price and increase the quality of public services. The residual costs of the extra public services can then be financed out of the other taxes paid by the new residents.

A natural fear if restrictions on mobility are relaxed is that cities with high wages will quickly develop shanty-towns on their periphery. To some degree this occurs already, due to the temporary residents who lack hukou status. An alternative to the hukou procedure for limiting the population of a city is to restrict residence to those who own or have signed a lease for a registered housing unit in the city, and perhaps meet occupancy restrictions (number of people per square meter). People can then move freely, and property values adjust as jurisdictions become more or less attractive. Competition among jurisdictions for residents still creates incentives on officials to provide higher quality public services, even if the population remains unchanged, since a more attractive jurisdiction attracts higher income residents, who consume more and so pay more in consumption taxes. Property values also rise, leading to greater property tax payments.

One factor inhibiting mobility is the lack of a market for farmland. Those working in agriculture then face the potential loss of much of the value of this use-right to the land if they migrate. Only if the utility gain is large enough, given these hurdles, will those currently working in agriculture move. With easier transfers of use rights, there would be greater mobility and more pressure on officials to provide the efficient level of public services.

\footnotetext{
${ }^{29}$ However, as we discussed earlier, a policy of the central government that preserves at least 1.8 billion $\mathrm{mu}$ of agricultural land could be serving as a means of collusion among different generations of officials to keep the value of non-agricultural land permanently higher than agricultural land.
} 


\section{Conclusions}

The Chinese economy has benefited dramatically from the decentralization of decisionmaking to individual firms and workers, regarding what to produce, how to organize production, and where to work. The question focused on in this paper is the feasibility of an equivalent decentralization within the government. China, like the United States, has a federal system of government, with national, provincial, county, municipal, and village levels of government. Given the huge size and diversity of the country, it is difficult for the national government to make allocation decisions for all of these different levels of government, just as it was difficult for the national government to make allocation decisions for all of the many firms in the economy. To what degree can decentralized decision-making within the government lead to more efficient outcomes? This can occur only to the degree that the economic incentives faced by local officials are designed appropriately.

In this paper, we examined the economic incentives faced by local officials in China over the course of the economic reforms. In doing so, we made use of a number of the standard presumptions in the Tiebout model. In particular, we assumed that local officials benefit from the tax revenue received by their jurisdiction plus any income from renting or selling land minus the costs of public services. Given these financial incentives, what allocation decisions do we expect local officials to make? The behavior of local officials forecast by the model, to our mind, corresponds closely to the stylized facts we see in the data. If we accept this model as a valid characterization for how officials behave, then the model provides a mechanism to help guide the redesign of these incentives in order to induce officials to allocate resources more efficiently. Potential reforms were discussed briefly, though many others may also reduce the inefficiencies that result under current incentives.

\section{References}

Bai, C.-E., Y. Du, Z. Tao, and S. Y. Tong, Local protectionism and regional specialization: evidence from China's industries, Journal of International Economics, 63(2), 397-417, 2004.

Banerjee, A., and E. Duflo, Addressing absence, The Journal of Economic Perspectives, 20(1), 117-132, 2006.

Buchanan, J. M., and G. Tullock, The Calculus of Consent, University of Michigan Press, Ann Arbor, 1962.

Gordon, R. H., and W. Li, The change in productivity of Chinese state enterprises, 19831987, Journal of Productivity Analysis, 6, 5-26, 1995. 
Gordon, R. H., and W. Li, Taxation and economic growth in China, in Critical Issues in China's Growth and Development, edited by Y. K. Kwan and E. S. H. Yu, pp. 22-40, City University of Hong Kong, Ashgate, 2005.

Grossman, G., and E. Helpman, Protection for sale, American Economic Review, 84, 833-50, 1994.

Groves, T., Y. Hong, J. McMillan, and B. Naughton, Autonomy and incentives in Chinese state enterprises, Quarterly Journal of Economics, 109, 183-209, 1994.

Hussain, A., and N. Stern, Public finances, the role of the state, and economic transformation, 1978-2020, in Public Finance in China: Reform and Growth for a Harmonious Society, edited by J. Lou and S. Wang, pp. 13-38, The World Bank, Washington, D.C., 2008.

Li, W., The impact of economic reform on the performance of Chinese state enterprises,1980-1989, Journal of Political Economy, 105(5), 1080-1106, 1997.

Li, W., A tale of two reforms, Rand Journal of Economics, 30, 120-136, 1999.

O'Brien, K. J., and L. Li, Accommodating "democracy" in a one-party state: Introducing village elections in China, The China Quarterly, (162), 465-489, 2000.

Wang, F., and X. Zuo, Inside china's cities: Institutional barriers and opportunities for urban migrants, The American Economic Review, 89(2), 276-280, 1999.

$\mathrm{Xu}, \mathrm{C}$. , The institutional foundation of China's reform and development, University of Hong Kong Working Paper, 2010.

Young, A., The razor's edge: Distortions and incremental reform in the People's Republic of China, The Quarterly Journal of Economics, 115(4), 1091-1135, 2000. 


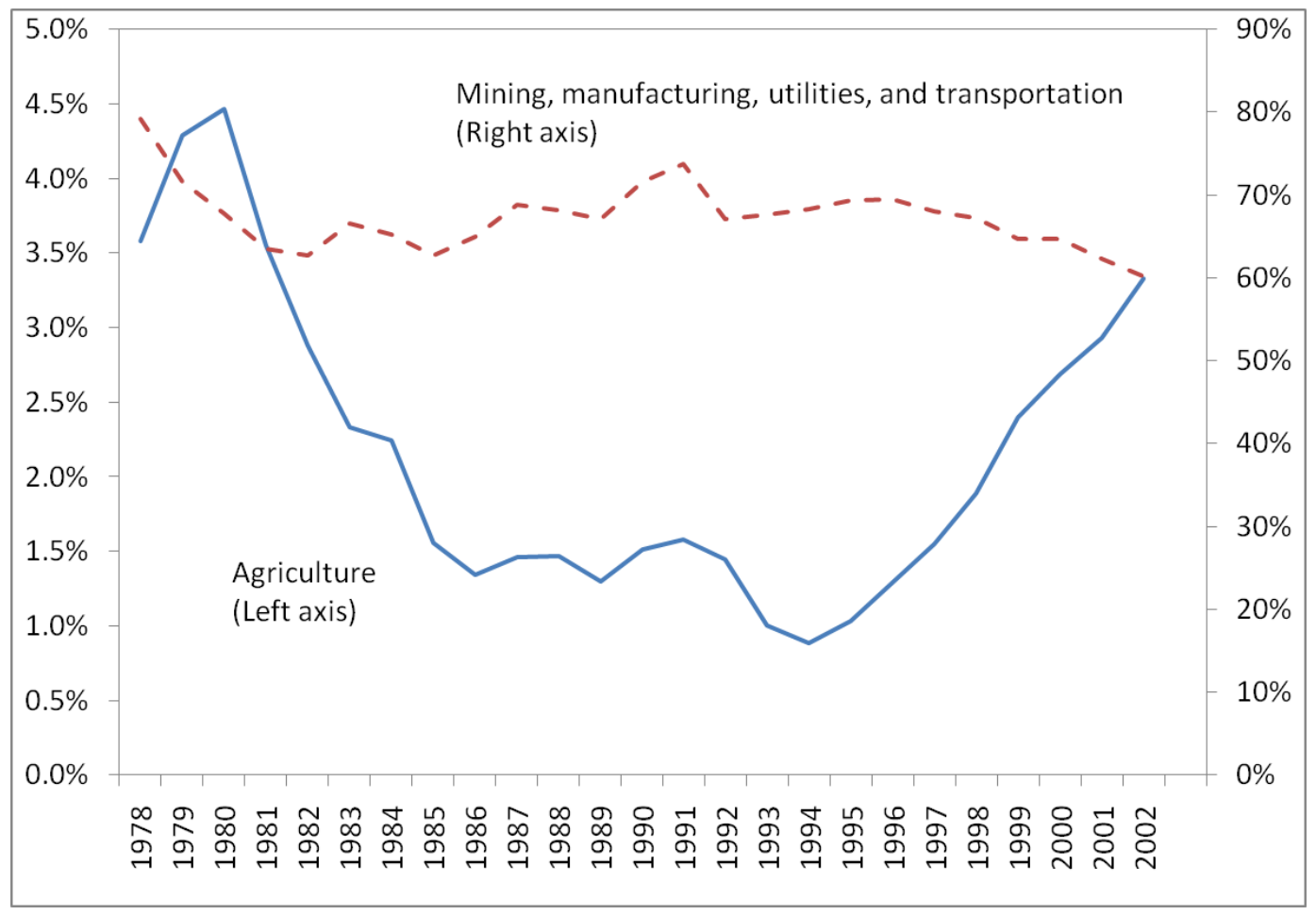

Figure 1: Share of capital construction investment allocated to agriculture and to industry (mining, manufacturing, utilities, and transportation) between 1978 and 2002. Source: National Bureau of Statistics of China (NBS). (From 2003, NBS stopped reporting capital construction investment and replaced it with fixed asset investment, a broader measure of capital formation.) 


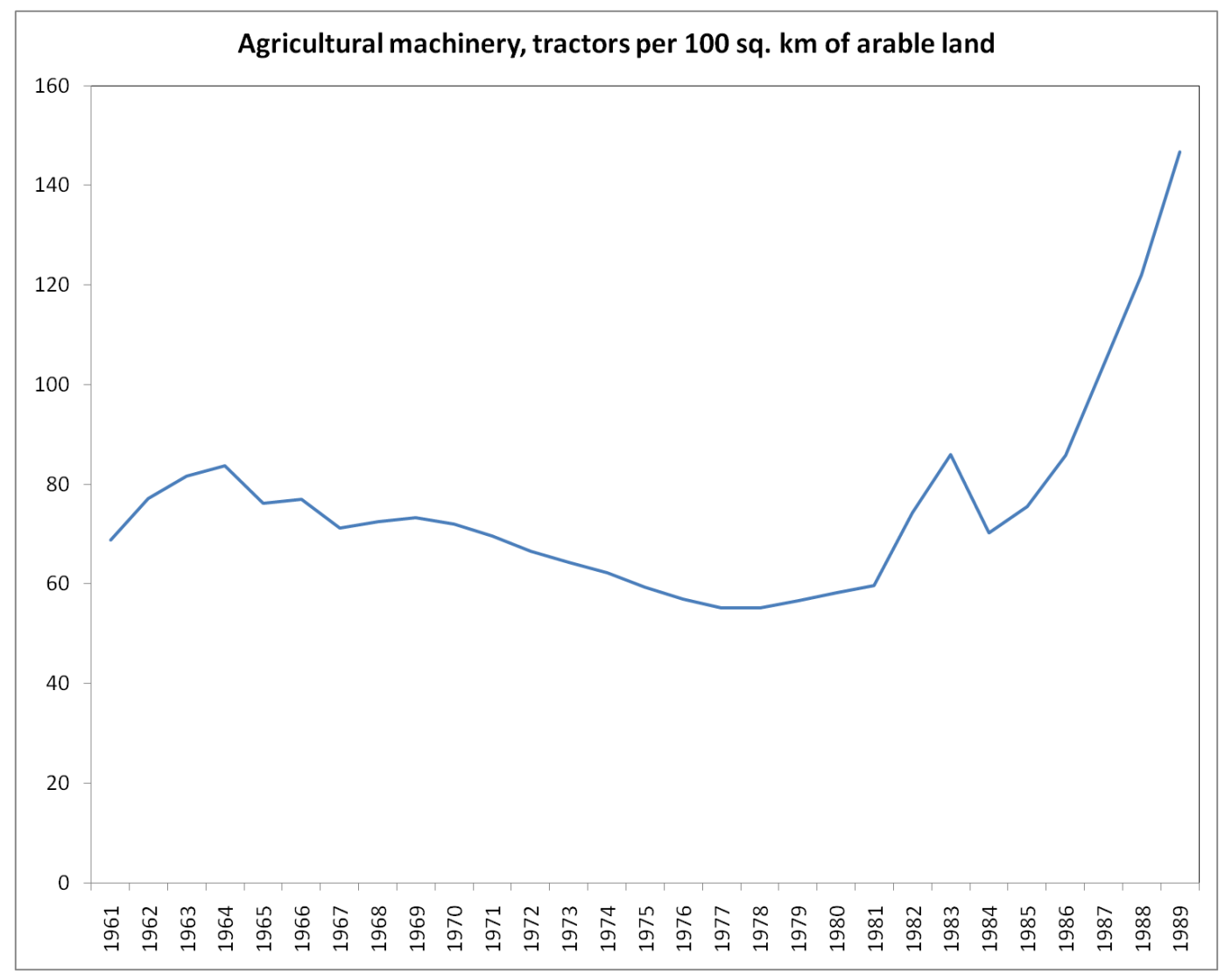

Figure 2: Agricultural machinery: number of tractors per 100 square kilometers of arable land bewteen 1979 and 2007. Source: National Bureau of Statistics of China (NBS). 


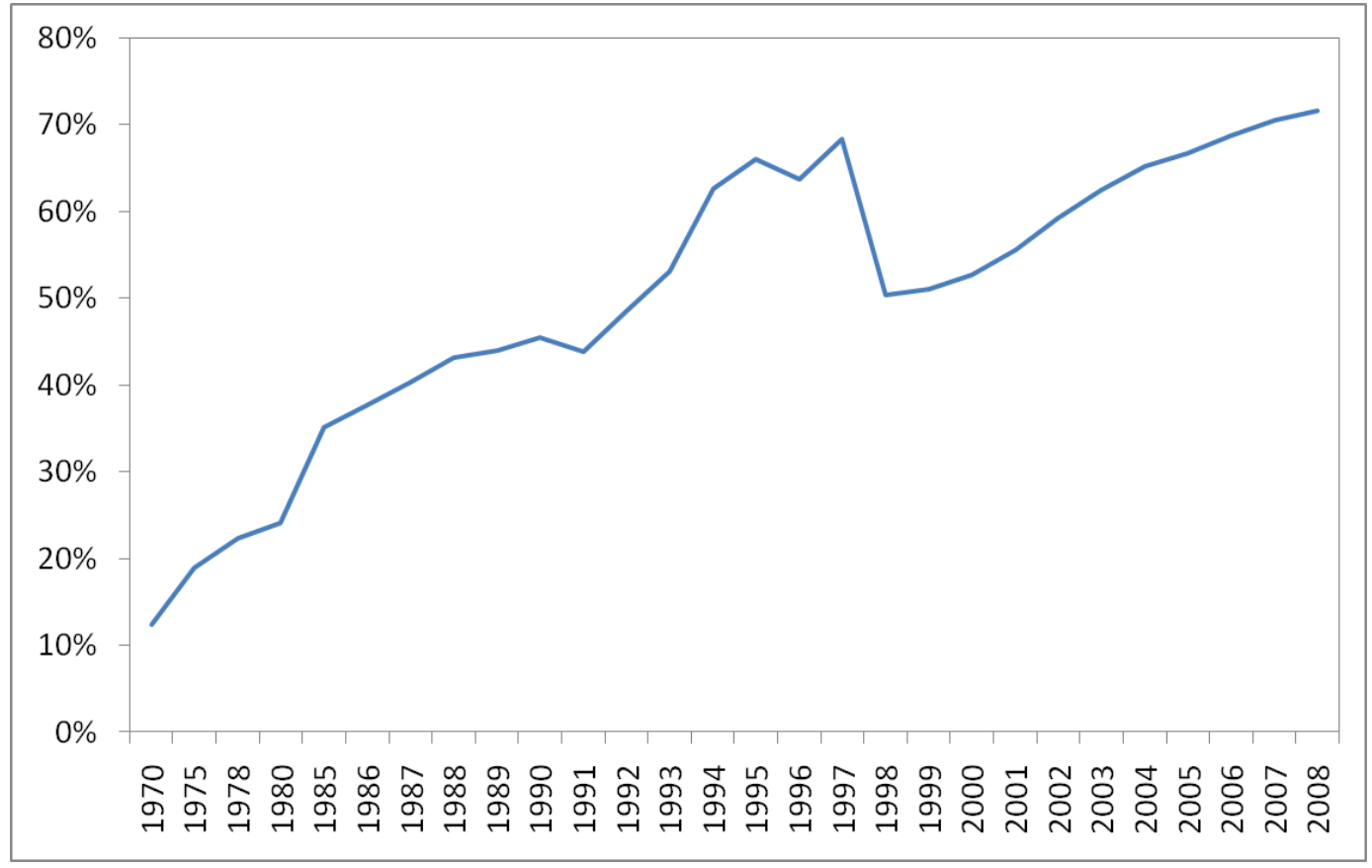

Figure 3: Share of non-state-owned enterprises in gross industrial output. The large drop in the share in 1998 was a result of a change in sampling methodology that excludes non-state enterprises with annual sales less than 5 million yuan. Source: China Statistical Yearbook 2009, National Bureau of Statistics of China. 


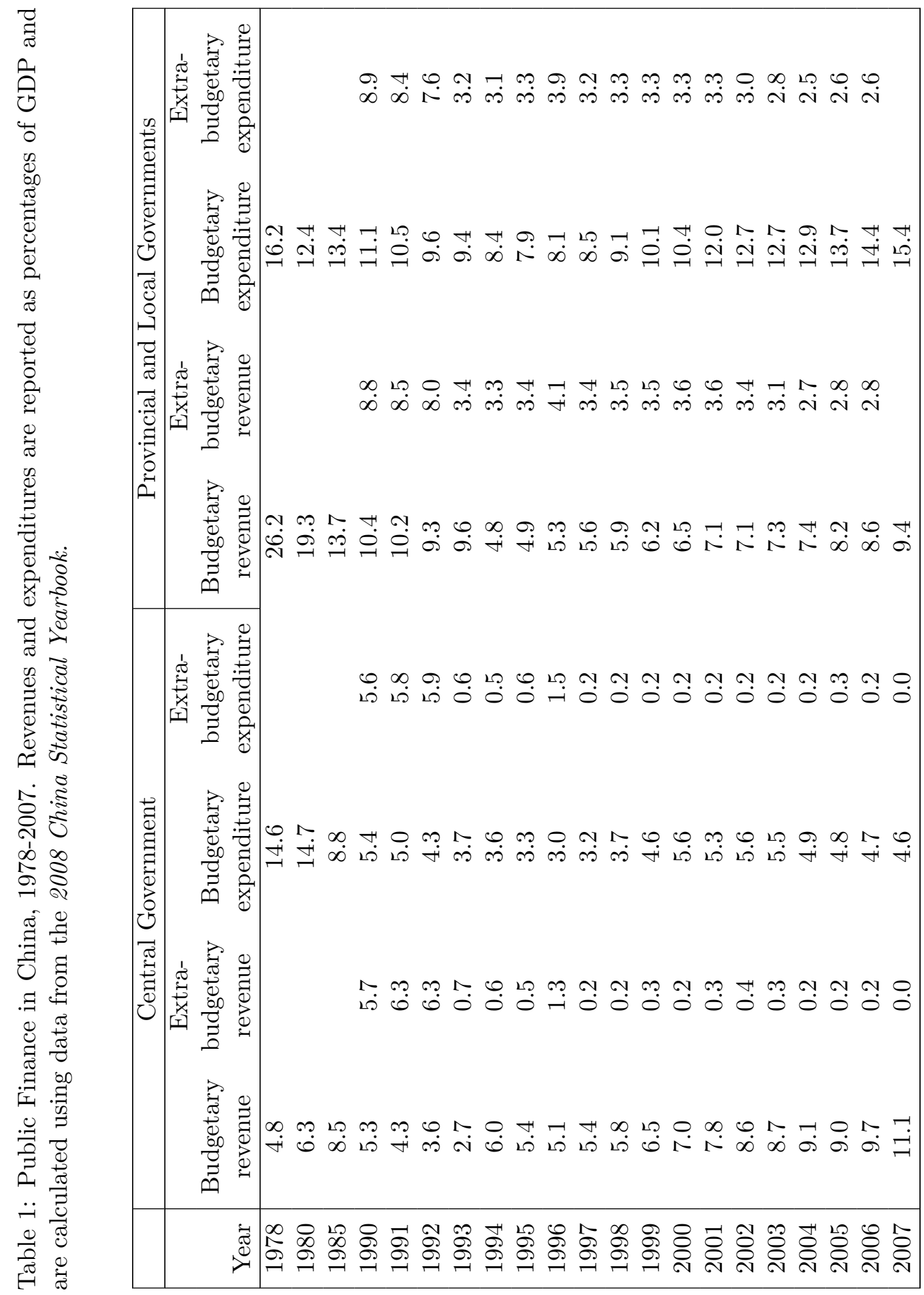


Table 2: Tax and Non-Tax Revenues as Percentages of GDP, 1978-2007. The tax and non-tax items listed in the table are incomplete. We selected a few items that are relevent to our discussion in the paper. The sum of the parts is therefore smaller than the total. Source: China Statistical Yearbook 2008, National Bureau of Statistics of China.

\begin{tabular}{|c|c|c|c|c|c|c|c|c|}
\hline \multirow[b]{4}{*}{ Year } & \multirow[b]{4}{*}{ Total } & \multirow[b]{3}{*}{$\operatorname{Tax}$} & \multicolumn{3}{|c|}{ Tax Revenue } & \multicolumn{3}{|c|}{ Non-Tax Revenue } \\
\hline & & & Industrial & & Corporate & Remitted & & \\
\hline & & & Commercial & Agricultural & Income & $\mathrm{SOE}$ & Subsidies & Education \\
\hline & & Revenue & $\operatorname{Tax}$ & $\operatorname{Tax}$ & $\operatorname{Tax}$ & Profits & to SOEs & Fee \\
\hline 1978 & 31.1 & 14.2 & 12.7 & 0.8 & & 15.7 & & \\
\hline 1980 & 25.5 & 12.6 & 11.2 & 0.6 & & 9.6 & & \\
\hline 1982 & 22.8 & 13.1 & 11.7 & 0.6 & & 5.6 & & \\
\hline 1984 & 22.8 & 13.1 & 11.2 & 0.5 & & 3.8 & & \\
\hline 1985 & 22.2 & 22.6 & 12.2 & 0.5 & 7.7 & 0.5 & -5.6 & \\
\hline 1986 & 20.7 & 20.3 & 11.7 & 0.4 & 6.7 & 0.4 & -3.2 & \\
\hline 1987 & 18.2 & 17.7 & 10.6 & 0.4 & 5.5 & 0.4 & -3.1 & \\
\hline 1988 & 15.7 & 15.9 & 9.9 & 0.5 & 4.5 & 0.3 & -3.0 & \\
\hline 1989 & 15.7 & 16.1 & 10.4 & 0.5 & 4.1 & 0.4 & -3.5 & \\
\hline 1990 & 15.7 & 15.1 & 10.0 & 0.5 & 3.8 & 0.4 & -3.1 & \\
\hline 1991 & 14.5 & 13.7 & 9.1 & 0.4 & 3.4 & 0.3 & -2.3 & 0.1 \\
\hline 1992 & 12.9 & 12.2 & 8.3 & 0.4 & 2.7 & 0.2 & -1.7 & 0.1 \\
\hline 1993 & 12.3 & 12.0 & 9.0 & 0.4 & 1.9 & 0.1 & -1.2 & 0.1 \\
\hline 1994 & 10.8 & 10.6 & 8.1 & 0.5 & 1.5 & & -0.8 & 0.1 \\
\hline 1995 & 10.3 & 9.9 & 7.5 & 0.5 & 1.4 & & -0.5 & 0.1 \\
\hline 1996 & 10.4 & 9.7 & 7.4 & 0.5 & 1.4 & & -0.5 & 0.1 \\
\hline 1997 & 11.0 & 10.4 & & 0.5 & 1.2 & & -0.5 & 0.1 \\
\hline 1998 & 11.7 & 11.0 & & 0.5 & 1.1 & & -0.4 & 0.1 \\
\hline 1999 & 12.8 & 11.9 & & 0.5 & 0.9 & & -0.3 & 0.1 \\
\hline 2000 & 13.5 & 12.7 & & 0.5 & 1.0 & & -0.3 & 0.1 \\
\hline 2001 & 14.9 & 14.0 & & 0.4 & 2.4 & & -0.3 & 0.2 \\
\hline 2002 & 15.7 & 14.7 & & 0.6 & 2.6 & & -0.2 & 0.2 \\
\hline 2003 & 16.0 & 14.7 & & 0.6 & 2.1 & & -0.2 & 0.2 \\
\hline 2004 & 16.5 & 15.1 & & 0.6 & 2.5 & & -0.1 & 0.2 \\
\hline 2005 & 17.3 & 15.7 & & 0.5 & 2.9 & & -0.1 & 0.2 \\
\hline 2006 & 18.3 & 16.4 & & 0.5 & 3.3 & & -0.1 & 0.2 \\
\hline 2007 & 20.6 & 18.3 & & 0.6 & 3.5 & & & \\
\hline
\end{tabular}




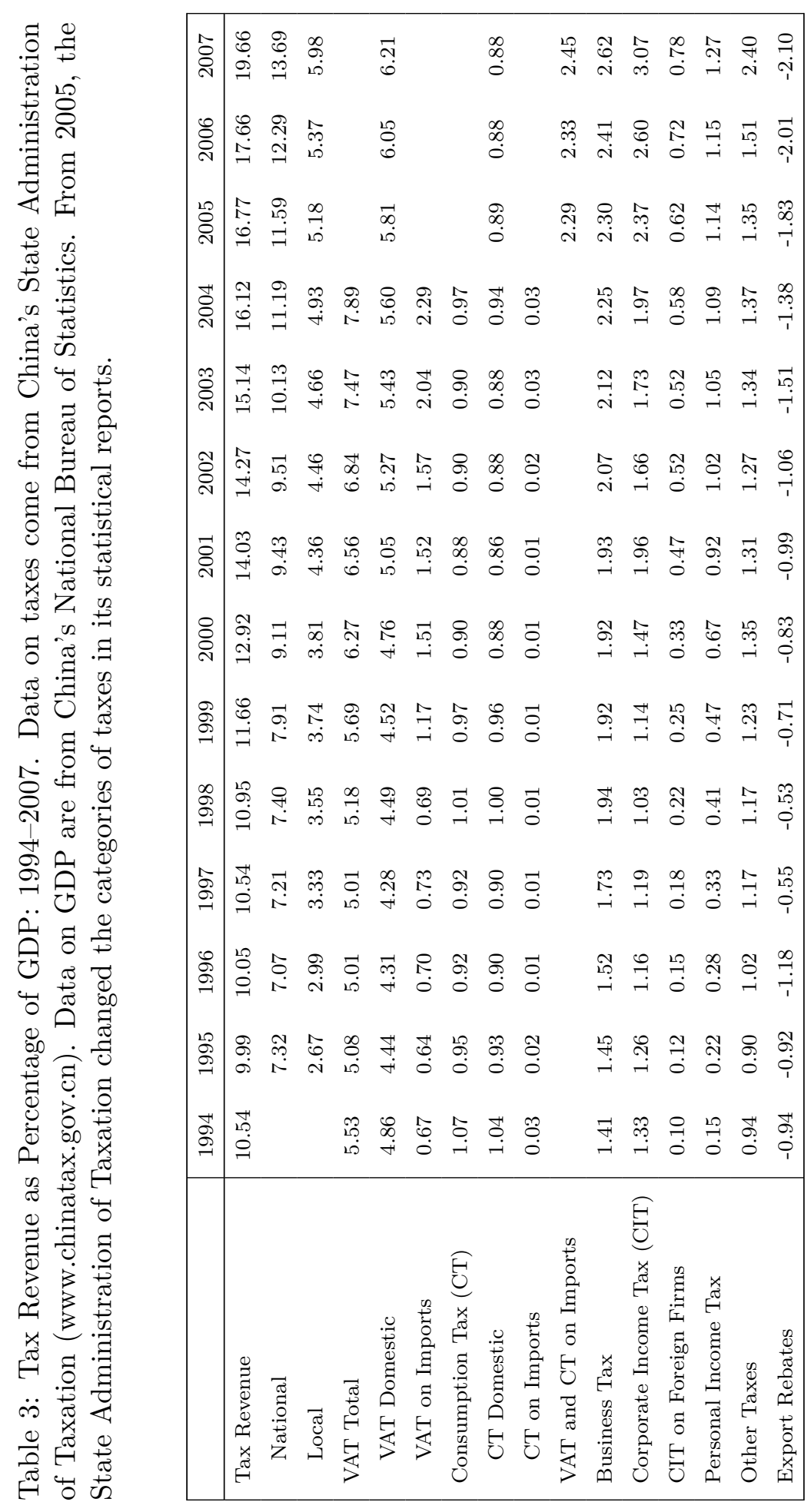


Table 4: Local Government Budgetary Expeditures by Selected Programs, as Percentages of Total Budgetary Expenditures. Source: China Statistics Yearbook 200\%, National Bureau of Statistics of China.

\begin{tabular}{|c|c|c|c|c|c|c|c|}
\hline Year & $\begin{array}{c}\text { Capital } \\
\text { Construction }\end{array}$ & Agriculture & $\begin{array}{c}\text { Culture, } \\
\text { Eduation, } \\
\text { Science }\end{array}$ & Education & $\begin{array}{c}\text { Services to } \\
\text { Industry } \\
\text { Communications } \\
\text { \& Distribution }\end{array}$ & $\begin{array}{c}\text { Social } \\
\text { Subsidies }\end{array}$ & $\begin{array}{c}\text { Social } \\
\text { Insurance }\end{array}$ \\
\hline 1991 & 8.46 & 9.61 & 27.19 & 16.26 & 1.63 & 2.91 & \\
\hline 1992 & 8.7 & 9.39 & 27.3 & 15.97 & 1.72 & 2.56 & \\
\hline 1993 & 8.47 & 8.74 & 25.65 & 15.34 & 1.57 & 2.24 & \\
\hline 1994 & 7.26 & 8.78 & 28.22 & 17.5 & 1.58 & 2.33 & \\
\hline 1995 & 8.51 & 7.95 & 27.34 & 16.99 & 1.42 & 2.37 & \\
\hline 1996 & 8.8 & 7.87 & 26.66 & 16.61 & 1.44 & 2.19 & \\
\hline 1997 & 8.72 & 7.53 & 25.63 & 15.75 & 1.44 & 2.1 & \\
\hline 1998 & 10.14 & 7.26 & 24.93 & 15.83 & 0.98 & 2.15 & 1.77 \\
\hline 1999 & 11.75 & 6.74 & 23.8 & 15.44 & 0.97 & 1.97 & 3.6 \\
\hline 2000 & 10.54 & 6.65 & 23.64 & 15.67 & 1.04 & 2.03 & 5.33 \\
\hline 2001 & 12.54 & 6.23 & 22.85 & 15.5 & 1.06 & 2.02 & 5.69 \\
\hline 2002 & 12.37 & 6.43 & 23.11 & 15.93 & 1.08 & 2.42 & 6.29 \\
\hline 2003 & 11.07 & 5.8 & 23.2 & 15.65 & 1.16 & 2.87 & 6.49 \\
\hline 2004 & 10.17 & 7.54 & 22.45 & 15.28 & 1.35 & 2.7 & 6.45 \\
\hline 2005 & 10.64 & 6.54 & 21.93 & 14.83 & 1.4 & 2.83 & 6.28 \\
\hline 2006 & 9.55 & 6.46 & 22.04 & 14.74 & 1.47 & 2.96 & 6.19 \\
\hline
\end{tabular}

